\title{
Mobile Phone Use for English Language Learning in a Dominican Republic University Classroom: A Qualitative Inquiry
}

\author{
Gisela Martiz, Mimi Recker \\ Utah State University \\ Corresponding author: gisela.martiz@gmail.com
}

\begin{abstract}
This qualitative case study investigated the use of mobile phones as tools to support English language learning in a higher education setting in the Dominican Republic. The study examined how a Dominican English language teacher and her students used mobile phones as educational tools, and which features these participants appropriated to engage in English language learning activities inside and outside the classroom. The study also explored social and physical factors that influenced participants' mobile phone appropriation in a developing country context with limited technology access and infrastructure. Data collection took place for eight weeks through semi-structured interviews, informal conversations, classroom observations, and questionnaires, in a university English language center located in a Dominican urban city.

Findings indicated that the teacher appropriated her mobile phone as a tool for connectivity, content delivery, assessment facilitation, time-management, and emergency power back-up.

Students appropriated their mobile phones as tools for research and reference, note-taking, data gathering, collaboration and repository. In addition, mobile phone use for educational purposes facilitated the teacher's instruction and enabled her to provide authentic activities for her students. Findings from this study shed light on how English Language teachers and students can integrate their own mobile technologies to support English language learning in a university classroom within a developing country context with uneven access to technology.
\end{abstract}

Martiz, G., Recker, M. (2019) Mobile Phone Use for English Language Learning in a Dominican Republic University Classroom: A Qualitative Inquiry. Computer-Based Learning in Context, 1(1), 14-27.

\section{Introduction}

Learning the English language has become a critical component for young adult professional development in Latin American countries, including the Dominican Republic (DR) (Alvarez Marinelli, 2016; El idioma Inglés es Fundamental," 2008). The DR is a developing country that is part of the Greater Antilles in the Caribbean region. This location makes the country attractive for several industries, including international trade as well as tourism. These industries provide growing opportunities for employment to those who master the English language.

However, as a developing country, the DR faces several challenges that impact its educational system, including how English language instruction is provided. Like many developing countries, educational systems are hampered by various challenges, such as a lack of trained teachers, lack of affordable access to quality educational resources, prohibitive tuition for enrolling in courses, among others (Glewwe \& Kremer, 2006; Glewwe \& Muralidharan, 2016).

Similarly, the country has significant technological and infrastructural challenges. For example, for decades the Dominican electrical system has been overloaded, resulting in recurrent power outages in large parts of the country (Observatorio, 2018). Educational institutions are not exempt from these black-outs. In addition, access to technology in the DR is unequally distributed within the population (Velasquez, 2012). For example, results from a survey reported that in 2015, only about $30 \%$ of Dominican homes had computers (Enhogar, 2018), which was below the $38 \%$ average in Latin-American countries (Dominguez \& Lara, 2016). Another report showed that only about $16 \%$ of homes had broadband Internet service (Gomez Mazara, 2017). In addition, although efforts have been made to provide educational institutions at all academic levels with technology resources, many classrooms serving low-income students are still lacking in basic technology access (Coronado, Cantú \& Rodríguez, 2014; Gómez Mazara, 2017).

Technology is increasingly a critical component in adult English language learning throughout the world (Vanderplank, 2010). Effective integration of technology in the English as a Foreign Language (EFL) classroom has been shown to facilitate learning grammar, acquiring vocabulary, listening comprehension development, and reading fluency, among other aspects, as well as exposing students to the cultural knowledge needed to communicate in the 
target language (Levy, 2009; Vanderplank, 2010). Thus, without adequate technology access, EFL students in the DR are at a disadvantage, and this may interfere with meaningful opportunities for learning.

Despite the limited access to technological resources in many English language classrooms in the DR, most people in this country possess a genre of technology with great potential for educational use: mobile phones 1 (Domínguez \& Lara, 2016; Gómez Mazara, 2017).

Recent data show that about $94 \%$ of people over the age of twelve in the DR use mobile phones (Enhogar, 2018). Therefore, mobile phones present an opportunity for English language teachers and students to explore the potential of a technology readily at hand to enhance their language learning experience.

Mobile Learning in Language Teaching. The rapid evolution of technology has led to increasing use of mobile devices, and many researchers and instructors are embracing these technologies for educational purposes, implementing what is called mobile learning; that is, learning with the assistance of small portable, network connected digital devices available to the learner when needed (Ally, 2009; Ferreira, Klein, Freitas \& Schlemmer, 2013; Kukulska-Hulme \& Shield, 2008; Pollara \& Kee Broussard, 2011). Mobile learning research has been implemented in foreign and second language education, with mobile phones being the most studied mobile devices (Bodzdogan, 2015; Burston, 2014; Chinnery, 2006; Kukulska-Hulme 2009). Both qualitative and quantitative approaches have reported positive outcomes in what is known as Mobile Assisted Language Learning (MALL), where learning is facilitated by the mobility of the learner and/or the portability of mobile devices (Chinnery, 2006; Kukulska-Hulme \& Shield, 2008). For example, positive outcomes include that mobile technologies helped promote learning, and increased motivation and participation of students (Begum, 2011; Gromik, 2012; Cavus \& Ibrahim, 2009; Palalas, 2011), facilitated student access to information, and enabled students to create their own context and content for learning (Kukulska-Hulme, 2010; Lim Abdullah, Hussin, Asra \& Zakaria, 2013; Ros i Sole, Calic \& Neijmann, 2010).

Despite the widespread interest in investigating the use of mobile devices for educational purposes across different fields, our review of the literature found that most existing research had been conducted in North America, Europe, and Asia (Burston, 2015; Cheung \& Hew, 2009; Lamptey \& Boateng, 2017). Similarly, in the field of foreign language teaching, the majority of research studies were conducted in East and South Asia (e.g., China, Japan, Korea, Indonesia, Philippines, Turkey) (Burston, 2014; Bozdogan, 2015). In Latin America, MALL research had been limited, with early studies conducted in few countries, such as Mexico, Colombia, Chile, and Brazil (Camacho \& Lara, 2011; Jara, Claro and Martinic, 2012; Tsinakos, 2013). Most recently, research in this area is growing in more Latin American countries, largely due the growth in the use of instant messaging and mobile apps to support language learning (García Botero \& Questier, 2016; Vásquez-Cano \& García, 2015).

Design Process. In this paper, we describe the design evolution of Ibigkas!, a mobile game that supports the development of English literacy in children from 9 to 12 years old. We were interested in the perspectives of both teachers and learners, hence we elicited knowledge and design ideas from both these stakeholders, consulting and iterating multiple times using partial outputs from the previous stages. This allowed us to elicit feedback from both stakeholders, improving design ideas for each iteration.

\section{Study Purpose and Research Questions.}

As described earlier, many young adult learners in Dominican classrooms have limited access to high-end technology resources, such as laptops and a high-speed Internet connection, to support language learning. Thus, in this context, mobile phones represent an affordable way to integrate modern technology into the EFL classroom and provide innovative ways to encourage students' meaningful language learning.

The purpose of this study was to investigate how a Dominican English language teacher and her students appropriated mobile phones for educational purposes inside and outside of their EFL classroom. The study also investigated which mobile phone features enabled the participants to appropriate these mobile devices for the implementation of different learning activities in a Dominican context. This study is guided by the following research questions:

(i) How does a Dominican EFL teacher appropriate mobile phones inside and outside the classroom? Which mobile phone features enable this appropriation for language learning activities in a Dominican context?

(ii) How do Dominican EFL students appropriate mobile phones inside and outside the classroom? Which mobile phone features enable this appropriation for language learning activities in a Dominican context? 
Theoretical Perspective: Mobile Human-Computer Interaction. The theoretical perspective informing this exploratory and naturalistic study was the mobile human computer interaction (MHCI) perspective (Botha, Greunen \& Herselman, 2010; Love, 2005; Winters \& Price, 2005). MHCI is defined as "the relationship (interaction) between people and mobile computer systems and the applications that they use on daily basis" (Love, 2005, p. 2).

From a pedagogical viewpoint, MHCI is a useful way to look at how English language learners can make use of the features in their mobile phones to carry out activities to enhance their learning experience (Dourish, 2001; Love, 2005). In particular, this study looked at the teacher's and students' appropriation of their mobile devices in this instructional context (Carroll, Howard, Peck, Murphy, 2002; Cook \& Pachler, 2011; Salovaara, 2006), mobile phone features that enabled this appropriation (Kukulska-Hulme, 2012), and social and physical factors in the context of interaction that influenced participants' appropriation of their mobile phones (Caudill, 2007; Dourish, 2004; Wali, Oliver \& Winters, 2009).

Based on our literature review of MHCI, we developed a framework to examine mobile phone appropriation within this Dominican learning context (Figure 1). In this framework, appropriation can be defined as exploring, adapting, and adopting new uses for features in a technology, going beyond its intended regular use (Carroll et al., 2002; Cook \& Pachler, 2011; Waycott, 2004). People appropriate technologies like mobile phones for daily activities in varied ways, depending on their goals and skill levels (Alberts, 2013). Further, Pachler, Bachmair and Cook (2010) argue that mobile phones can be considered cultural artifacts, used to mediate activities such as communication and recreation. Here, the focus is on how learners, through appropriation, use their mobile phones for needs that go beyond simply making calls or texting, and instead adopting new practices according to their learning context. Dey (2001) defines context as the information learners use to describe the situation of an entitypeople, places, or objects- relevant to the interaction between the learner and the artifact.

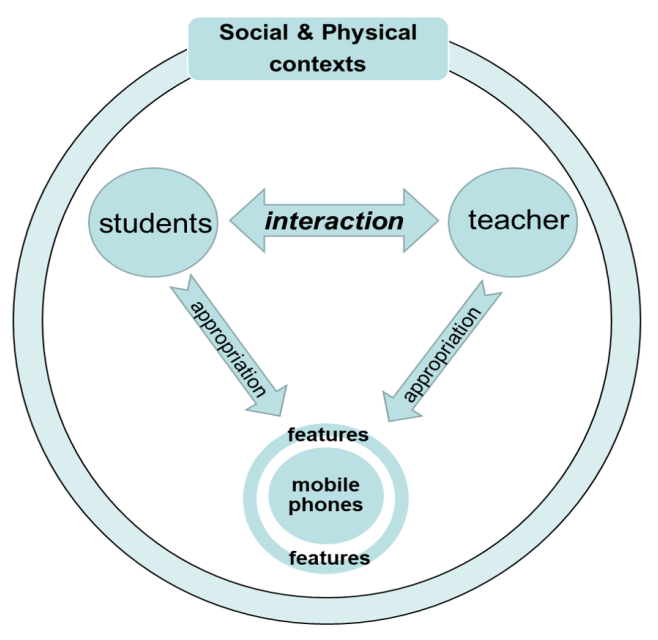

Figure 1. MHCI Theoretical Perspective

When students take advantage of the information that is available through people, locations, technology, and objects around them, they are making use of context in different ways to achieve more efficient and effective learning (Kukulska-Hulme \& Wible, 2008). This context can be physical: classroom and other locations where learning can occur, lighting, noise level, and even temperature. Context can also be social: people's interactions, their habits and daily practices, and the rules and norms inside and outside of the classroom. We thus use the MHCI perspective to examine how the teacher and student participants appropriated specific features in their mobile phones to integrate them for educational use inside and outside of the classroom. We examine how this appropriation was mediated by the social and physical contexts in which the participants interacted. 


\section{Methodology}

This study followed a qualitative case study approach to examine activities taking place in their natural settings, since the purpose was to interpret the events from the participants' point of view (Creswell, 2008; Maxwell, 1996; Mertens, 2010). An exploratory case study approach was also selected because its design calls for a detailed description of the situation, topic or issue under investigation (Merriam, 2009; Mertens, 2010) within its real-life context (Maxwell, 1996; Hancock \& Algozzine, 2006). When a researcher wishes to explore a phenomenon within a unit of analysis or bounded system, a case study approach is appropriate (Creswell, 2008; Merriam, 2009). In this particular case study, the unit of analysis or bounded system consisted of the Dominican English language teacher and the students who appropriated their mobile phones for language learning activities.

Sampling Criteria and Participants. Purposeful sampling was used to select the participants that could best relate to the phenomenon under study (Creswell, 2008, 2012; Merriam, 2009). Participants selected were:

- A Dominican female teacher with five years of experience in teaching English as a foreign language to children and young adults. The teacher owned an iPhone $5 \mathrm{~S}$ and was generally familiar with the use of technology for educational purposes.

- A class consisting of twenty-three young adult students, seven males and sixteen females.

All were university students, between the ages of 18 and 24. The setting was an English center located in the facilities of a public university in the DR. This center offered ten-month intensive English programs, with cycles of seven weeks each.

Power outages were common in this area in the afternoons and evenings, and the building did not have an emergency back-up power generator. Equipment in the English classrooms at this center consisted of a radio with a CD player that teachers borrowed for the duration of class. Occasionally, the teacher supplied additional technology, including her personal laptop, speakers, and a projector.

Data Sources. The period of data collection was eight weeks, covering one complete cycle of the English program. Data sources included questionnaires, classroom observations, semi-structured interviews, and informal conversations. Student participants completed a pre-questionnaire which provided a general view on students' mobile technology ownership and access, as well as their prior experiences with mobile phones as educational tools for English language learning. At the end of the study, the students completed a post-questionnaire that addressed how they used their mobile phones for language learning activities during that cycle, as well as students' general perceptions on the use of their mobile devices as learning tools.

A total of five classes were observed in the classroom during the period of data collection. During these observations, structured field notes were taken, documenting how the teacher and students were using their mobile phone features as part of educational activities inside the classroom.

Two semi-structured interviews (pre and post respectively) were conducted with the teacher and seven volunteer students from the class. The pre-interview occurred at the beginning of the cycle, and the post-interview took place during the last week of classes. While the teacher interviews were in English, student interviews were in Spanish to ensure their understanding of questions and clarity in their responses. In addition, informal conversations with the interviewees occurred at the end of classroom observations, which added valuable contextual information to field notes. Secondary data sources included the teacher's lesson plans that served to support her statements and the observations in the classroom. In addition, several student participants showed examples of how they were using their mobile phones.

Data Analysis. Data analysis followed the six-step process of thematic analysis (Braun \& Clarke, 2006): (1) familiarizing with the data, (2) generating initial codes, (3) searching for themes, (4) reviewing themes, (5) defining and naming themes, (6) producing the report. Data steps 2 to 5 were coded following Saldaña's first stage of data analysis (Saldaña, 2012) through open coding and in vivo coding, and the second stage through focused and axial coding, to answer the two main research questions for this study.

The credibility and trustworthiness of this study were achieved with the use of validation strategies including triangulation, researcher reflexivity, detailed description, member checking, and peer debriefing (Merriam, 2009). Triangulation took place by comparing findings across the analyzed data: participants' interview transcripts, informal conversations, classroom observation field notes, and questionnaire responses. Participants' voices through quotes allowed for a detailed description of the themes. Participants reviewed their interview transcripts and 
preliminary findings to corroborate that their thoughts were accurately put into writing and were then translated into English. A bilingual graduate student familiar with the study reviewed the material translated, and colleagues who were familiar with the qualitative research process provided feedback on the coding process.

\section{Findings}

Data analysis identified several emerging themes on how the teacher and students appropriated different mobile phone features for learning activities inside the classroom and homework assignments, and for students' personal and informal learning purposes. The categories or themes addressing each research question were distilled based on the educational intention of the activity or activities implemented with the support of any mobile phone feature.

RQ1. Teacher Appropriation of Mobile phone for educational purposes. Major themes emerged from the data analysis indicated that the teacher appropriated mobile phones to implement in-class and homework learning activities in several ways. The teacher considered mobile phone features that helped facilitate her instruction and student learning within the limitations and opportunities present in her classroom. This facilitation could be directly related to pedagogical purposes (e.g. enhancing meaningful learning and improving language skills). These included directed uses of a mobile phone as a connectivity tool, content delivery tool, and assessment facilitation tool. Additionally, mobile phones integration facilitated complementary uses that enabled the accomplishment of several purposes: time-management and time-saving tool, and emergency back-up tool.

Mobile phone as a connectivity tool. The university did not provide access to Wi-Fi in the classroom, thus preventing the use of mobile phones for activities that required Internet connection, such as just-in-time access to information or clarification. The teacher indicated that her iPhone $5 \mathrm{~S}$ was on a post-paid plan with unlimited data. She was able to use this phone feature to enable Internet access:

As you could see, some of them [the students] did have Internet connection, they had Internet access, but they didn't want to spend it in class, because that was their money. So, we would share my hotspot with them. I would group them and would share it because there would always be at least one willing to do it [using the mobile phone as hotspot]. (Post-interview)

Thus, the teacher utilized her mobile device and at least one other student's mobile device as a connectivity tool by using the hotspot feature, which enabled students to have data, and increased Internet access to search for class-related information.

Mobile phone as content-delivery tool. In this English center, teachers often used radios to play the textbook CD that contained the listening exercises. However, the amount of radios available was limited, and at times the teacher would not be able to get one for use in her class. Plus, power-cuts occurred often and unexpectedly, disrupting the pace of the class. To address this issue, she converted the CD tracks into mp3 files, which she uploaded to the class Dropbox account for student access, and also played them through her mobile phone audio playback feature.

Another example of mobile phone as content-delivery tool was its use to play songs in English. Some participants stated they felt more motivated with these type of activities since listening to music in English was part of their recreational social practices. The teacher typically played popular songs as a kind of fill-in-the gap activity in order to develop students' listening comprehension skills and to support learning phrasal verbs in context:

I did a lot of fill in the gap [activities] with lyrics because they [students] were introduced to phrasal verbs, and that's one of their favorite activities. And that allowed me to do this in the right context, how to draw the different meanings a phrasal verb could have according to the way or how you are applying it, right? (Post-interview)

Mobile phone as assessment facilitation tool. The teacher indicated that providing individual assessment and feedback to students was challenging, due to the limited amount of time in class to work with each student, and the overall fast pace of the instruction. Thus, she implemented some assessment activities on reading and pronunciation with the assistance of the audio-recording feature in her students' mobile phones and the Dropbox app: 
It was impossible for me to see, I mean to target each and every one of them [the students]. So that was genius, that was one of my favorites personally, that they can take advantage of their mobile phone in a way that they don't need Internet for it. Some of them were not able to upload them [the recordings] to Dropbox, so they just brought me their mobile phones, and during break I would listen to it. That is perfect! (Post-interview)

In this quote, the teacher referred to an assignment where students recorded themselves with their mobile phones having a conversation in English about their preferences for different types of music, and the type of emotions evoked by them. This was an exercise from a topic addressed in one of the textbook units, but the teacher had students bring their own experiences and interests into the classroom. When Internet access was not available at home or through mobile data, some students would use public Wi-Fi connections to upload their recordings to Dropbox.

Mobile phone as time-management and time-saving tool. An intensive English language program progresses at an accelerated pace in its instruction. In informal conversations, the teacher pointed out that she needed to make sure she spent only a specific amount of time on each aspect of the day's lesson, including group and individual activities. Classroom observations revealed that there was no clock in the classroom. The teacher used the timer in the clock function of her mobile phone to time students work on book exercises and other activities, thus appropriating her device as a tool for better time-management in her classroom activities. She would also occasionally ask students to check their phones and tell her the time in English.

In addition, the integration of mobile phone features in the instruction brought another advantage: saving time. Throughout informal conversations and the post-interview, the teacher repeatedly stated that activities done with mobile phones were time-saving in several ways for both her and the students. For example, she used an online tool, Survey Any Place (https://surveyanyplace.com), in order to assess and provide feedback to students in a shorter amount of time:

I found a great resource that is called Survey Any Place. So, in a way even though it was a little bit of sacrifice for me [to set up the test], it was like a plus in another way because they got the results right away [on their mobile phones], they didn't have to wait for me to take 23 sheets home to correct them 1 by 1. It was something for them productive at that time being, so in that way it was good. (Post-interview)

The time the teacher invested in setting up the quizzes was compensated with the time she saved in assessment because Survey Any Place helped by providing immediate feedback to students. Although not all students completed the quizzes on their mobile phones, this activity represented an innovative way to take students outside the traditional paper-based assessment, and provide immediate feedback.

Mobile phone as emergency back-up power tool. The teacher mentioned other useful aspects of her mobile phone for her teaching enabled by the long battery life and flashlight feature in her iPhone $5 \mathrm{~S}$. As mentioned above, power outages are common across the DR, and this English language center was no exception. Although the classroom was in an illuminated location and classes took place in the afternoon, on some rainy days they would have blackouts that would make the instruction delivery difficult. At these times, the teacher would turn on the flashlight on her phone to better light up the classroom:

Just as the [lack of] radios situation, it's the same as when you have blackouts. My mobile phone wouldn't die out. It's like I plug in my speakers and you're ready to go. You don't have any disruption. You know what I mean? And it never got too dark thanks God, as if it would rain and we got a blackout at the same time, I have a flashlight, and most of them do too. (Post-interview/Informal conversations) 
Table 1. Teacher Appropriation of Mobile phones

\begin{tabular}{|c|c|c|c|c|}
\hline & Function/feature & Enabled & Theme identified & Sample Codes \\
\hline \multirow{3}{*}{ Pedagogical Use } & Hotspot & $\begin{array}{l}\text { Increased data } \\
\text { access }\end{array}$ & Connectivity tool & $\begin{array}{l}\text { No Wi-Fi in classroom } \\
\text { Smartphone with unlimited } \\
\text { data } \\
\text { Share hotspots with students }\end{array}$ \\
\hline & $\begin{array}{l}\text { Audio } \\
\text { playback/music } \\
\text { player }\end{array}$ & $\begin{array}{l}\text { Rich-media } \\
\text { playback }\end{array}$ & Content delivery tool & $\begin{array}{l}\text { play CD content on phone } \\
\text { plug speakers on phone } \\
\text { Play exercises directly from } \\
\text { mobile phone }\end{array}$ \\
\hline & $\begin{array}{l}\text { Audio-recording } \\
\text { /playback }\end{array}$ & $\begin{array}{l}\text { Rich-media } \\
\text { capturing }\end{array}$ & $\begin{array}{l}\text { Assessment facilitation } \\
\text { tool }\end{array}$ & $\begin{array}{l}\text { Listen to their own mistakes } \\
\text { Provide feedback on } \\
\text { pronunciation mistakes }\end{array}$ \\
\hline \multirow{2}{*}{$\begin{array}{l}\text { Complementary } \\
\text { Use }\end{array}$} & Clock & $\begin{array}{l}\text { Efficiency/ } \\
\text { time control }\end{array}$ & $\begin{array}{l}\text { Time-management \& } \\
\text { time-saving tool }\end{array}$ & $\begin{array}{l}\text { Saves time } \\
\text { Activities completed faster }\end{array}$ \\
\hline & $\begin{array}{l}\text { Battery Power } \\
\text { Flashlight }\end{array}$ & $\begin{array}{l}\text { Power source/ } \\
\text { illumination }\end{array}$ & $\begin{array}{l}\text { Emergency back-up } \\
\text { power tool }\end{array}$ & $\begin{array}{l}\text { Plug my speakers } \\
\text { I have a flashlight in it }\end{array}$ \\
\hline
\end{tabular}

Table 1 above presents a summary of the teacher's findings, with the mobile phone features that enabled educational appropriation of mobile phones. The table also lists the emerging themes, with sample codes along with their data source.

RQ2. Student Appropriation of Mobile phones for Educational Purposes. Pre-questionnaire findings. According to the responses on the pre-questionnaire, all students owned mobile devices. Smartphones were the most popular mobile technologies owned by the students, although some participants reported owning both a smartphone and a regular phone as well (Figure 2).

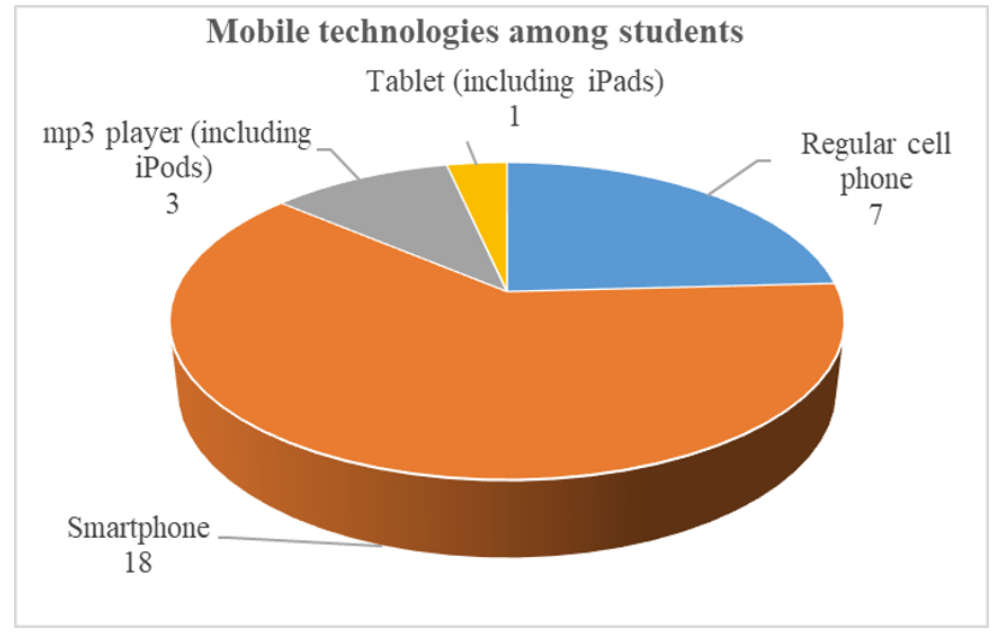


Figure 2. Mobile technology ownership among student participants

Students reported that they mostly used pre-paid cards for calls and texts, with only three students reporting ownership of post-paid data plans. Students accessed the Internet through their mobile phones in several ways, but mainly from Wi-Fi connections, particularly at home or at their workplace (Figure 3).

Regarding students' previous experiences in mobile phone use for English language learning purposes, the majority indicated that the frequency of mobile phone use in the EFL classroom initiated by teachers was minimal, whereas the personal use for learning was more common. The pre-questionnaire also revealed that most students did not think they could integrate their own mobile phones for teacher-guided activities in the classroom, while being more positive on using these mobile devices on their own for learning purposes outside of the classroom.

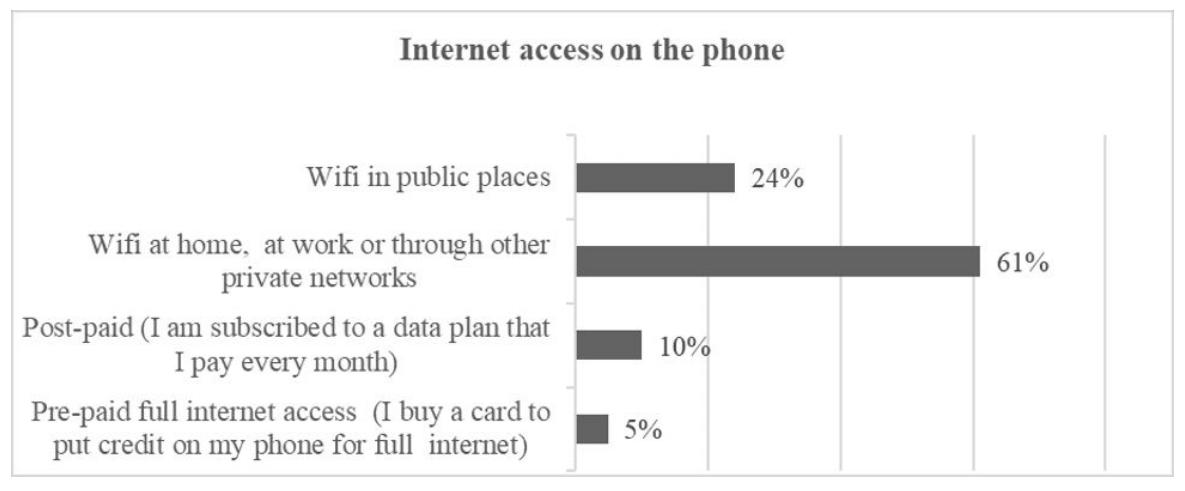

Figure 3. Student mobile Internet access

Post-questionnaire findings. Results drawn from the post-questionnaire showed that student participants had generally positive perceptions on the educational appropriation of mobile phones during this teaching cycle. In contrast to the pre-questionnaire findings, most respondents agreed that using mobile phones to complement instruction in the classroom was helpful and provided more opportunities for learning.

Students appropriated their mobile phones for learning activities inside and outside of the English language classroom with the teacher's assistance and on their own initiative. These activities supplemented the traditional learning practices to which these students were accustomed, while also allowing for more real-word applications.

Mobile phone as a collaboration tool. Mobile phones are intrinsically devices for communication. They thus enhance the opportunities for students to collaborate beyond the classroom or teacher's guidance. Mobile e-mail and instant messaging apps like WhatsApp enabled students in this class to appropriate these mobile devices as collaboration tools. For example, some participants noted that outside of the classroom, they shared class material stored in their phones through mobile email, or discussed topics about class presentations through a WhatsApp group. As one participant stated:

For instance, we have a class presentation tomorrow, I was talking with one of the guys, and we were discussing the topic through there [WhatsApp], about what we would talk about, because we only have 10 minutes, and there are five of us. So, we send the information that way [through the WhatsApp group]. I say, look this is what I plan to present, but we can summarize it from there. (Pre-interview)

Mobile phones as reference and research tools. The ability to download different types of dictionary apps to their mobile phones enabled students to have instant offline access to different meanings of words, phrases and idiomatic expressions, as well as to check for correct word pronunciation. The appropriation of mobile phones as reference tools was already popular among students in this class, where most students replaced physical dictionaries with these apps. Results from the post-questionnaire indicated that about eleven of the students used the dictionary app on a regular basis. 
Mobile phone as data gathering and note-taking tool. Sometimes the teacher had a lot of material to cover in one day, and needed to rush when writing some notes on the board. For example, one student noted:

Well, sometimes, when I don't have much time to jot down some notes, I take a picture of it. Then at home I write it in a notebook. But not all the time, that is when I'm in a rush or when I have to do something. (Post-interview)

In order to save time, this and other students would use their mobile phone cameras, which enabled them to capture the information from the board, and later reference or transcribe it into their notebooks.

Mobile phone as repository. Student participants also reported that having class content downloaded on their smartphones allowed access to English language material in different locations. As stated previously, the teacher uploaded class materials to Dropbox, and students could install the Dropbox app in their smartphones. For some students, downloading the files to their mobile phones enhanced content access, as they could have educational material available offline. One of the student participants was a heavy user of Dropbox, and pointed out that he was taking advantage of this app by saving all the files on his phone, so that he did not have to rely on Internet access, and instead access class material while on the move.

Table 2 below shows a summary of emerging themes on student appropriation, with code examples extracted from student interview transcripts, informal conversations and observation field notes, and questionnaires' open-ended responses.

As seen in this section, the teacher participant perceived that mobile phone educational use in her instruction facilitated her goal of helping students utilize everyday English, and going beyond classroom content. In addition, mobile phone appropriation as described above provided more realistic tasks for her students. Besides, findings showed that most student participants had positive opinions on the educational use of mobile phones in general.

\section{Discussion}

Findings from this study provided examples of how the participants used mobile phones as tools for learning purposes both inside and outside of the EFL classroom. Using a MHCI perspective (Botha, Greunen \& Herselman, 2010; Love 2005; Winters \& Price, 2005), we examined how the social and physical contexts where the teaching-learning process occurred influenced the teacher and student participants' appropriation of different mobile phone features to create and implement in-class and out of class learning activities. (Traxler, 2011; Winters \& Price, 2005). 
Table 2. Student Mobile Phone Appropriation

\begin{tabular}{|c|c|c|c|}
\hline Function/feature & Enabled & Appropriated as & Sample Codes \\
\hline $\begin{array}{l}\text { Instant Messaging App } \\
\text { (WhatsApp) } \\
\text { Mobile Email } \\
\text { Dropbox }\end{array}$ & $\begin{array}{l}\text { Communication / } \\
\text { information exchange }\end{array}$ & Collaboration tool & $\begin{array}{l}\text { Share audio-files } \\
\text { Assist other classmates } \\
\text { Share things with Dropbox } \\
\text { Work focused as a group }\end{array}$ \\
\hline $\begin{array}{l}\text { Dictionary App / } \\
\text { Mobile } \\
\text { Web browser } \\
\text { Language learning } \\
\text { apps }\end{array}$ & Information access & Reference \& Research tool & $\begin{array}{l}\text { Dictionary App provide } \\
\text { definitions and pronunciation } \\
\text { Help understand meanings of } \\
\text { words } \\
\text { Use mobile phone to look for } \\
\text { meanings } \\
\text { Looking up words in different } \\
\text { contexts } \\
\text { Look things up in the Internet } \\
\text { Look up info about grammar } \\
\text { topics } \\
\text { Research topics }\end{array}$ \\
\hline $\begin{array}{l}\text { Picture camera } \\
\text { Notes App/feature }\end{array}$ & Image capturing & $\begin{array}{l}\text { Data gathering/ Note } \\
\text { taking tool }\end{array}$ & $\begin{array}{l}\text { Take pic from the board } \\
\text { Taking pics of notes } \\
\text { Snap pic from the book } \\
\text { Use Notes App }\end{array}$ \\
\hline $\begin{array}{l}\text { Mobile phone } \\
\text { datamemory / } \\
\text { Drop-box app }\end{array}$ & $\begin{array}{l}\text { Data storage } \\
\text { File sharing \& storing }\end{array}$ & Repository & $\begin{array}{l}\text { Download files from Dropbox } \\
\text { to phone } \\
\text { Access files offline } \\
\text { More storage in the phone } \\
\text { Save notes from Dropbox }\end{array}$ \\
\hline
\end{tabular}

The teacher explored the potential of mobile phone features in terms of her students' language learning needs, as well as in terms of the opportunities and limitations in both the social and physical aspects of the classroom context. Similarly, students explored the individual advantages that their respective mobile phones provided. Like the teacher, students adapted the properties of these features to improve their language skills in ways that otherwise would not have been possible, or more difficult to achieve. By doing this, student participants ended up modifying their language learning practices inside and outside the classroom.

Likewise, student participants' mobile phone appropriation for learning activities was bounded by their social and physical contexts (Carroll et al., 2002; Simoes \& Gouveia, 2011; Wali et al., 2007). Table 3 highlights key social and physical components in terms of opportunities and limitations that influenced the teacher and student participants' mobile phone educational appropriation. 
Table 3. Social and physical aspects of context

that influenced teacher and student mobile phone appropriation

Social Context

Opportunities:

- Integrating students' interests into the instruction (e.g. contemporary pop music)

- Authentic contexts to practice the target language

- Collaboration through social networks with peers

\section{Limitations}

- No mobile phone allowed policy in the English language center

- Saving mobile data for recreation use due to high costs

\section{Physical Context}

Opportunities:

- Immediate access to information

- Mobility and portability

- Sharing content across locations

- Wi-Fi access in other settings

\section{Limitations}

- No Wi-Fi in the classroom

- Limited mobile data in students' mobile phones

- Few radios available

- Power-outages

In terms of the social aspect, students' personal interests were important drivers that facilitated the educational appropriation of mobile phones. For example, although the English textbook provided exercises for students to practice phrasal verbs, the teacher replaced these exercises with more appealing options to students, such as incorporating popular songs by some of their favorite American artists. By integrating elements from learners' everyday life experiences, the teacher created tasks that allowed them to practice the second language in engaging and authentic contexts (Kukulska-Hulme, 2012; Pachler et al., 2010).

Another social factor that fostered student appropriation of mobile phones is that students could connect easily with each other and collaborate with their peers through different social networking sites, accessed through their phones, thereby expanding their classroom community into a virtual environment. Traxler (2010) points out the important role that mobile devices, along with messaging applications, like WhatsApp, play in supporting a virtual community where students' learning can be enhanced.

Limitations in the social aspect were also present in this classroom, and they influenced how mobile learning activities took place. Banning mobile phone use in educational settings is one of the most common challenges that mobile learning advocates face. Therefore, norms for use of mobile phones in this context posed a challenge to the teacher. Although it was not a hard and fast rule in the institution, a known traditional policy was that mobile phones were not allowed in the classroom. This teacher carefully addressed this challenge by pointing out to her students and the administration the purpose of having mobile phones available during her classes. She was conscious that for the integration of mobile phones to be accepted, she needed to adhere to the norms and protocols established within the institution (Traxler, 2010).

Students' socio-economic background was another social factor influencing mobile phone appropriation in this classroom. Most students were not willing to spend minutes from their pre-paid mobile data plans on classroom activities, instead preferring to save them for more recreational uses. This drove the teacher to think about using her mobile phone hotspot as a connectivity tool to provide students with access to the Internet. As costs of mobile data are still considerably high in the DR, many young adults prefer to rely on Wi-Fi connections. This factor is consistent with the findings from previous studies in developing countries, where student participants reported being at a disadvantage when they needed to incur expenses to access mobile learning activities (Churchill \& Churchill, 2008; Lee, as cited in Kukulska-Hulme \& Shield, 2008; Kukulska-Hulme, Norris \& Donohue, 2015).

The physical aspect of the classroom context also presented opportunities and limitations that needed to be considered for mobile phone appropriation. Some of the opportunities included that the teacher could take advantage of the close physical proximity of students inside the classroom to facilitate group work that required the use of only a few mobile phones. Outside the classroom, students could enhance their language learning experience wherever they could connect to Wi-Fi. In the DR, free Wi-Fi is available in locations such as home, workplace, malls, and other public spaces. Students could use these spaces to complete assignments and other learning activities using their mobile phones. An intrinsic affordance of mobile phones is that their small size allows them to be carried around almost all the time (Caudill, 2007; Kukulska-Hulme \& Traxler, 2005). The mobility and the portability of mobile 
phones blurs the line between the physical and virtual spaces where they can be used (Kukulska-Hulme, 2012; Traxler, 2010). That is, mobile phone users are not confined to a fixed location, but can move across places when learning with these devices. These advantages allowed the teacher to incorporate and suggest activities where everybody could share and engage with educational content in various locations.

The limitations in the physical context were critical factors influencing the teacher's exploration of mobile phone features to meet her students' learning needs. As reported earlier, the lack of Wi-Fi in the building and the limited mobile data in students' smartphones were the two main constraints, but also the two main drivers for the teacher to explore other options to take advantage of mobile phones. Additionally, little availability of radios and frequent power outages prompted the teacher to use features in her mobile phones to support instruction that overcame these obstacles.

\section{Conclusion}

Findings from this study provided insights on how teacher and students appropriated their personal mobile devices to support educational practices within the opportunities and limitations existing in the social and physical contexts of a language learning center in the DR. The research objective was to shed some light on how to address unequal access to technology in an EFL classroom in the DR by exploring ways for the effective implementation of activities in which teachers and students can make use of mobile technologies. This study addressed the use of teacher's and students' own mobile devices in authentic settings. Unlike other studies in the field, participants did not use loaned devices and there was no intervention using researcher-designed activities. This factor ensured a more naturalistic inquiry; it also ensured that MALL activities were potentially more sustainable once the research was completed.

With the rapid evolution in technology, today's generation of learners, regardless of socio-economic background, are increasingly exposed to the latest mobile devices and the technology-mediated social activities they support. Mobile apps offer a wide range of opportunities for language learning using students' own devices (Rosell-Aguilar, 2017), opportunities that emerging MALL research in Latin America has started to consider (Andujar-Vaca \& Cruz-Martinez, 2017; García Botero \& Questier, 2016).

Still, more work needs to be done so that teachers and students can effectively and efficiently incorporate mobile technologies in the EFL classroom. Not only in the DR, but also in other Latin American countries, skepticism on the educational use of mobile devices is widespread among educational administrators, who see these more as distractors; teacher training on their educational uses also poses a challenge due to scarce funding and support to provide professional development on this topic (Chacón-Ortiz, Camacho-Gutierrez \& Heredia-Escorza, 2017). Future research should include an examination of the views of coordinators and other administration representatives within the participating institutions and how these views influence mobile phone appropriation for educational activities. Research should also examine barriers in training teachers in the innovative uses of emerging technologies within developing countries such as the DR.

Since the present study did not go beyond investigating the participants' perceptions using a qualitative approach, it is not intended to be fully generalizable. Nonetheless, future studies should also examine impacts on student learning and engagement with EFL through the use of mobile devices, as compared to more traditional classroom instruction.

Findings from this case study illuminate how a teacher and her students can creatively implement MALL activities in a Dominican EFL classroom with varied and limited access to technology resources. In particular, findings show how the teacher appropriated mobile phone features to address class learning objectives as well as meet her students' needs. As mobile phone use continues to grow rapidly around the world, these findings also pave the way for these kinds of EFL activities to be implemented in other developing countries with similar social, technological and physical contexts. 


\section{References}

Alberts, B. (2013). Technology appropriation revisited-Mediation theory as a new philosophy of technology for information systems research. Master thesis. University of Twente. Retrieved from http://essay.utwente.nl/62736/1/Berend_Alberts_-_BIT_Master_Thesis.pdf

Ally, M. (Ed.) (2009). Mobile Learning: Transforming the Delivery of Education and Training. Edmonton, Canada: Athabasca University Press.

Álvarez Marinelli, H. (2016). El inglés en América Latina. Ruta Maestra 16, 22 - 33. Retrieved from http://rutamaestra.santillana.com.co/edicion-16/el-ingles-en-america-latina/

Andújar-Vaca, A., \& Cruz-Martínez, M. (2017). Mobile instant messaging: WhatsApp and its potential to develop oral skills. Comunicar, 50 (25), 43-52. doi.org/10.3916/C50-2017- 04

Begum, R. (2011). Prospect for cell phones as instructional tools in the EFL classroom: A case study of Jahangirnagar University, Bangladesh. English Language Teaching. 4(1).

Botha, A., Greunen, D. V., \& Herselman, M. (2010, August). Mobile human-computer interaction perspective on mobile learning. Paper presented at the 6th Annual International Conference on Computing and ICT Research, Kampala, Uganda.

Bozdoğan, D. (2015). MALL revisited: Current trends and pedagogical implications. Procedia-Social and Behavioral Sciences, 195, 932-939. doi: 10.1016/j.sbspro.2015.06.373

Braun, V., \& Clarke, V. (2006). Using thematic analysis in psychology. Qualitative research in psychology, 3(2), $77-101$.

Burston, J. (2014). The reality of MALL: Still on the fringes. CALICO Journal, 31(1),

103-125. doi: http://dx.doi.org/10.11139/cj.31.1

Burston, J. (2015). 20 years of MALL project implementation: A meta-analysis of learning outcomes. $R e C A L L$ Journal, 27(1), 4-20.

Camacho, M. \& Lara, T. (2011). M-learning en España, Portugal y América Latina, Monográfico SCOPEO, 3. Retrieved from http://scopeo.usal.es/wp-content/uploads/2013/04/scopeom003.pdf

Carroll, J., Howard, S., Vetere, F., Peck, J., \& Murphy, J. (2002, January). Just what do the youth of today want? Technology appropriation by young people. In System Sciences, 2002. HICSS. Proceedings of the 35th Annual Hawaii International Conference on (pp. 1777-1785). IEEE.

Caudill, J. G. (2007). The growth of m-learning and the growth of mobile computing: Parallel developments. International Review of Research in Open and Distance Learning, 8(2).

Cavus, N., \& Ibrahim, D. (2009). M-learning: An experiment in using SMS to support learning new English language words. British Journal of Educational Technology, 40(1), 78-91.

Chacón-Ortiz, M., Camacho-Gutiérrez, D. \& Heredia-Escorza, Y. (2017). Conocimientos sobre aprendizaje móvil e integración de dispositivos móviles en docentes de la Universidad Nacional de Costa Rica. Revista Digital de Investigación en Docencia Universitaria, 11(1), 149-165 doi: http://dx.doi.org/10.19083/ridu.11.507

Cheung, W. S., \& Hew, K. F. (2009). A review of research methodologies used in studies on mobile handheld devices in K-12 and higher education settings. Australasian Journal of Educational Technology, 25(2), 153-183.

Chinnery, G.M. (2006). Emerging technologies, going to the MALL: Mobile assisted language learning. Language Learning \& Technology, 10 (1), 9-11.

Churchill, D., \& Churchill, N. (2008). Educational affordances of PDAs: A study of a teacher's exploration of this technology. Computers \& Education, 50(4), 1439-1450.

Cook, J., \& Pachler, N. (2011). Appropriation of mobile phones in and across formal and informal learning. In Digital Difference (pp. 145-158). SensePublishers

Coronado Cabrera, E., Cantú Valadez, M., \& Rodríguez Pichardo, C. (2014). Diagnóstico universitario sobre el uso de la TIC en el proceso de enseñanza-aprendizaje bajo la modalidad educativa presencial en Santo Domingo. Edutec, 50 DOI: https://doi.org/10.21556/edutec.2014.50.225

Creswell, J. W. (2008). Educational research: Planning, conducting and evaluating quantitative and qualitative research (3rd.ed). Upper Saddle River,NJ: Pearson Education

Creswell, J. W. (2012). Qualitative inquiry and research design: Choosing among five approaches (3rd Ed). Oakland High, $C A$ : Sage publications.

Dey, A. K. (2001). Understanding and using context. Personal and ubiquitous computing, 5(1), 4-7. DOI: https://doi.org/10.1007/s007790170019

Dominguez, B., \& Lara, D. (2016). Acceso a las TICS de los estudiantes y docentes del sector educativo público dominicano. Ministerio de Educación de la Rep. Dom.(MINERD). Retrieved from 
http://www.educando.edu.do/portal/wp-content/uploads/2017/10/Informe-Acceso-y-Tenencia-TIC_MINER D NOV 2016.pdf

Dourish, P. (2001). Where the action is: the foundations of embodied interaction. Cambridge, MA: The MIT Press

Dourish, P. (2004). What we talk about when we talk about context. Personal and ubiquitous computing, 8(1), 19-30. Retrieved from http://citeseerx.ist.psu.edu/viewdoc/download?doi=10.1.1.120.6827\&rep=rep1\&type=pdf

El idioma inglés es fundamental para el desarrollo profesional y personal de todo joven universitario. (2008, September 18). Noticias Universia. Retrieved from bit.ly/2Ex4tWA

El sector eléctrico dominicano: retos para el crecimiento económico. (n.d.). Observatorio De Políticas Sociales $Y$ Desarrollo, 2(3). http://www.opsd.gob.do/media/14838/boletin-15-el-sector-electrico-dominicano.pdf

Enhogar 2016 (2018). Encuesta nacional de hogares de propósitos múltiples. Oficina Nacional de Estadísticas. Retrieved from https://www.one.gob.do/publicaciones?ID $=2341$

Ferreira, J. B., Klein, A. Z., Freitas, A., \& Schlemmer, E. (2013). Mobile Learning: Definition, Uses and Challenges. Cutting-edge Technologies in Higher Education, 6, 47-82.

García Botero, G., \& Questier, F. (2016). What students think and what they do in a mobile assisted language learning context: new insights for self-directed language learning in higher education. In S. Papadima-Sophocleous, L. Bradley \& S. Thouësny (Eds), CALL communities and culture - short papers from EUROCALL 2016 (pp. 150-154). Research-publishing.net. https://doi.org/10.14705/rpnet.2016.eurocall2016.553

Glewwe, P., \& Kremer, M. (2006). Schools, teachers, and education outcomes in developing countries. Handbook of the Economics of Education, 2, 945-1017. Retrieved from bit.ly/2SZycA9

Glewwe, P., \& Muralidharan, K. (2016). Improving education outcomes in developing countries: Evidence, knowledge gaps, and policy implications. In Handbook of the Economics of Education (Vol. 5, pp. 653-743). Elsevier. Retrieved from bit.ly/2GKqt2n

Gómez Mazara, F. (2017) El computador como determinante del acceso a Internet en hogares de la República Dominicana. Ciencia, Economía \& Negocios 1(1). 39-85. DOI: http://dx.doi.org/10.22206/ceyn.2017.v1i1.pp39-85

Gromik, N. A. (2012). Cell phone video recording feature as a language learning tool: A case study. Computers \& Education, 58(1), 223-230. Retrieved from bit.ly/2Vkw8Q0

Hancock, D. R., \& Algozzine, B. (2006). Doing case study research: A practical guide for beginning researchers. New York, NY: Teachers College Press.

Jara, I., Claro, M. \& Martinic, R. (2012). Mobile learning for teachers in Latin America: Exploring the potential of mobile technologies to support teachers and improve practice. United Nations, Educational, Scientific and Cultural Organization. Retrieved from http://unesdoc.unesco.org/images/0021/002160/216081E.pdf

Kukulska-Hulme, A. (2009). Will mobile learning change language learning? ReCALL, 21(2), 157-165. doi:10.1017/S0958344009000202

Kukulska-Hulme, A. (2010). Learning Cultures on the Move: Where are we heading? Journal of Educational Technology and Society, 13(4), 4-14. Retrieved from http://oro.open.ac.uk/25679/1/Learning_Cultures_ETS_Agnes_Kukulska-Hulme.pdf

Kukulska-Hulme, A. (2012). Language learning defined by time and place: A framework for next generation designs. In Diaz-Vera, Javier, E. (eds.) Left to my own device: Learner autonomy and mobile assisted language learning. Innovation and Leadership in English Language Teaching, 6. Bingley, UK: Emerald Group Publishing Limited

Kukulska-Hulme, A., \& Shield, L. (2008). An overview of mobile assisted language learning: From content delivery to support collaboration and interaction. ReCALL, 20(3), 271-289. DOI: https://doi.org/10.1017/S0958344008000335

Kukulska-Hulme, A., \& Wible, D. (2008). Context at the crossroads of language learning and mobile learning. Proceedings of the International Conference on Computers in Education 2008 (pp. 205-210). Retrieved from http://www.apsce.net/ICCE2008/Workshop_Proceedings/Workshop_Proceedings_0205-210.pdf

Kukulska-Hulme, A., Norris, N., \& Donohue, J. (2015). Mobile pedagogy for English language teaching: A guide for teachers. London, England: British Council. Retrieved from bit.ly/2tB2XMG

Lamptey, H. K., \& Boateng, R. (2017). Mobile Learning in Developing Countries: A Synthesis of the Past to Define the Future. World Academy of Science, Engineering and Technology, International Journal of Social, Behavioral, Educational, Economic, Business and Industrial Engineering, 11(2), 443-450. 
Lim Abdullah, M., Hussin, Z., Asra, B., \& Zakaria, A. R. (2013). MLearning scaffolding model for undergraduate English language learning: bridging formal and informal learning. TOJET: The Turkish Online Journal of Educational Technology, 12(2), 217-233.

Levy, M. (2009). Technologies in use for second language learning. The Modern Language Journal, 93, 769-782. Retrieved from bit.ly/2H09NmQ

Love, S. 2005. Understanding Mobile Human-Computer Interaction (Information Systems Series (ISS)): Butterworth-Heinemann.

Maxwell, J. A. (1996). Qualitative research design: An interactive approach. Thousand Oaks, CA: Sage Publications

Merriam, S. B. (2009), Qualitative Research: A Guide to Design and Implementation. San Francisco, CA: Jossey-Bass

Mertens, D. M. (2010). Research and evaluation in education and psychology: Integrating diversity with quantitative, qualitative, and mixed methods. Thousand Oaks, CA: Sage Publications.

Pachler, N., Bachmair, B., \& Cook, J. (2010). Mobile learning: structures, agency, practices. New York: Springer

Palalas, A. (2011). Mobile-assisted language learning: Designing for your students. In S. Thouësny \& L. Bradley (Eds.), Second language teaching and learning with technology: Views of emergent researchers (pp. 71-94). Dublin, Ireland: Researchpublishing.net.

Pollara, P. \& Kee Broussard, K. (2011). Student Perceptions of Mobile Learning: A Review of Current Research. In Proceedings of Society for Information Technology \& Teacher Education International Conference 2011 (pp. 1643-1650). Chesapeake, VA: AACE.

Ros i Solé, C., Calic, J., \& Neijmann, D. (2010). A social and self-reflective approach to MALL. ReCALL, 22, 39-52.

Rosell-Aguilar, F. (2017). State of the app: A taxonomy and framework for evaluating language learning mobile applications. CALICO Journal, 34(2), 243- 258. doi: https://doi.org/10.1558/cj.27623

Saldaña, J. (2012): Saldaña, The coding manual for qualitative researchers. Thousand Oaks, CA: Sage.

Salovaara, A. (2006). Studying appropriation of mobile technologies. A paper presented in MobileHCI2006 Doctoral Consortium. Retrieved from http://www.hiit.fi/u/asalovaa/articles/salovaara-mobilehci2006-doctoral-consortium.pdf

Simoes, L., \& L. B. Gouveia. 2011. "Social Technology Appropriation in Higher Education”. Romanian Journal of Social Informatics, 8(16). Retrieved from http://www.ris.uvt.ro/wp-content/uploads/2012/01/ris16_portugalia.pdf

Traxler, J. (2010). Students and mobile devices. Research in Learning Technology, 18(2). 149-160. Retrieved from http://files.eric.ed.gov/fulltext/EJ893353.pdf

Traxler, J. (2011). Context in a wider context. Retrieved from http://www.medienpaed.com/Documents/medienpaed/19/traxler1107.pdf

Tsinakos A. (2013). State of mobile learning around the world. In Tsinakos, A. \& Ally, M. (Eds.) Global Mobile Learning Implementations and Trends. (pp. 4-44). China Central Radio \& TV University Press.

Vanderplank, R. (2010). Déjà vu? A decade of research on language laboratories, television and video in language learning. Language teaching, 43(01), 1-37. DOI: 10.1017/S026144480999026

Velasquez, D. (2012). Cultura digital en América Latina: Investigación Interuniversitaria, educación y evangelización. (Centro de Comunicación Educativa Audiovisual, CEDAL, 54, 165-179. Bogotá, Colombia: Panamericana, formas e impresos. Available at http://www.cedal.org.co/es/revista-interaccion/cultura-digital-en-america-latina 